Kant and Stoic Affections

Melissa Merritt

University of New South Wales

Email:m.merritt@unsw.edu.au

\begin{abstract}
I examine the significance of the Stoic theory of pathe (and related topics) for Kant's moral psychology, arguing against the received view that systematic differences block the possibility of Kant's drawing anything more than rhetoric from his Stoic sources. More particularly, I take on the chronically underexamined assumption that Kant is committed to a psychological dualism in the tradition of Plato and Aristotle, positing distinct rational and non-rational elements of human mentality. By contrast, Stoics take the mentality of an adult human being to be rational through and through, while recognising that this rationality is not normally in a state of health or excellence. I show how Kant's account of affections - chiefly the "affects" and "passions" that he identifies as targets of a duty of apathy — draws substantive lessons from his Stoic sources, and how he accepts on his own terms the monistic principles of Stoic moral psychology.
\end{abstract}

Keywords: Kant, Seneca, Cicero, Stoic moral psychology, pathè, morbi animi, emotions, apathy 


\section{Kant and Stoic Affections}

Melissa Merritt

University of New South Wales

\section{Introduction}

R.B. Jachmann, Kant's friend and biographer, reports that Kant "had fully absorbed the entirety of Greek and Roman classical literature", and still read the Roman authors with "much relish" in his final years of teaching — when he indeed "particularly studied Seneca for the purpose of his practical philosophy" (Groß 1912, 137-138). No one who reads the relevant works of Seneca and Kant can be surprised by this testimony. ${ }^{1}$ It is hard to ignore, for example, Kant's endorsement of apathy as "an entirely correct and sublime moral principle of the Stoic school" (Anth 7:253; see also MS 6:408), and his penchant for speaking of apathy's chief target - the "passions" or Leidenschaften - as culpable, self-inflicted diseases of mind (e.g. Anth 7:266). These are themes of obvious Stoic provenance that figure prominently in the work of Seneca. Yet commentators tend to assume that what Kant gets from the Stoics can be little more than arresting rhetoric: the systematic differences between them are too great, the thinking goes, to take any of this business very seriously. But this assumption, I will argue, is mistaken: Kant's account not only of the "passions", but of what I will call "affections" more broadly, is the product of serious and substantive engagement with Stoic moral psychology.

The Stoics developed their view of human psychology from Socratic intellectualism, distinctively arguing for a monism that rejects Platonic and Aristotelian commitments to rational and non-rational parts of the soul. For the Stoics, the mentality of an adult human being is rational through and through, though this rationality is not normally in a state of health or excellence, or otherwise developed to perfection. And so the desires and emotions that seem to assail us unbidden are, by the lights of their monism, to be understood as expressions of rational activity - and thereby in some sense the result of what we freely do, making us responsible for them. Critics, ancient and modern, suggest these claims are undone by simple and obvious facts. For some, the phenomenology of our assailment by these states ought to take priority over any theoretical commitment to monism. ${ }^{2}$ Others point to what looks for all the world like desires and emotions in non-rational animals and pre-rational children, and retort: surely these states

\footnotetext{
${ }^{1}$ As Kant gave his last lecture in 1796 (Naragon 2006), the relevant works include: Critique of Judgment (1790), Religion within the Bounds of Mere Reason (1793), Metaphysics of Morals (1797), and Anthropology from a Pragmatic Point of View (1798). Thanks to Sasha Newton for advice on the translation of Jachmann. 2 The Stoic Posidonius is sometimes interpreted as an eclectic who was moved by this line of thought (e.g., Sorabji 2000, 93-120; cf. Cooper 1999). See Schapiro (2009) for a contemporary version of this point, directed at the monistic moral psychology of T.M. Scanlon's What We Owe to Each Other.
} 
cannot, simply as such, require a rational mind?3 Seneca's allowance that "wild animals" can have anger-like impulses of "frenzy, ferocity, aggression", though they can have no genuine anger, because they lack reason (Ira 1.3.4), ${ }^{4}$ may smack of terminological trickery — and insult, rather than mollify, those critics. Seneca's point, though, is that these anger-like states are radically different in nature from the anger that can only be felt by a human being who has acquired reason.

What distinguishes these anger-like impulses of "frenzy, ferocity, aggression" from genuine anger, by Stoic lights? Both are a kind of impulse (bormê), which Brad Inwood explains as the "psychological event which determines or causes an action" (1985, 47). Neither impulse nor action, simply as such, requires a rational mind: Seneca says "nothing can be done without an impulse" (Ep 113.2) and devotes considerable discussion to the adept action of non-rational animals and pre-rational human beings (Ep 121). But the impulses of an adult human being are different in nature from those of a pre-rational child or a non-rational animal: they are rational impulses, expressions of (typically tacit) assent to complex proposition-like items — "sayables" (lekta), and specifically "assertibles" (axiomata) — that involve truth-apt evaluation of what is good or bad, or appropriate to do or not do. ${ }^{5}$ Rational impulses result from taking things to be a certain way, where both the taking and its assertible object require the resources of rationality. Inasmuch as the acquisition of reason, by Stoic lights, transforms human mindedness in a thoroughgoing way, it follows that an adult human being will have no non-rational impulses, no impulses that are not an expression of assent to a view of what is a reason for doing what. ${ }^{6}$

In analysing rational impulses as expressions of assent to axiomata, Stoics take them to be judgments of some kind: and the point holds for ordinary emotions and desires, or pathè, as a kind of rational impulse. Here a previously noted criticism naturally reasserts itself. Ordinary emotions characteristically feel a certain way. If Stoic monism cannot capture this phenomenology then so much the worse for the theory. Tad Brennan suggests a rejoinder when he remarks that the Stoics are interested in ordinary emotions as sources of bad action, and obstacles to virtue: "How they feel, whether as a matter of physiology or mood, is neither here nor there" in light of such explanatory ends $(2003,276)$. But Brennan's move strikes me as rather quick, at least as far as Seneca goes. To be sure, Seneca in De Ira is chiefly concerned with anger as a source of foolish and cruel human action; but he examines this topic through vignettes

\footnotetext{
${ }^{3}$ E.g. as Galen complains in his polemic against Chrysippus (PHP 2.1.1, 3.7.11-12, and 5.5.1-3); for a contemporary version, see Copp and Sobel $(2002,258)$, also aimed at Scanlon (see n2).

${ }^{4}$ Also Cicero (TD 4.31).

${ }^{5}$ See Shogry $(2019,37-8)$ for helpful discussion.

${ }^{6}$ For an interpretation that underscores this point, consider Frede (2011, 34-42).
} 
often of such vivid colour that we are not left to forget how anger feels. Moreover, Seneca considers the phenomenology of assailment that is standardly taken to be characteristic of ordinary desires and emotions, suggesting that anger offers a particularly strong form of it: "All other vices give our minds a shove; anger pitches them headlong [praecipitat]" (Ira 3.1.4; see also 1.7.4). With these observations, Seneca invites the criticism we are considering: fidelity to the phenomenology of ordinary emotions is incompatible with the monistic principles of Stoic psychology. Yet Seneca's response, as I will suggest, is to offer a pointedly monistic account of pathe that accommodates their phenomenology.

This paper considers the significance of the Stoic theory of affections for Kant. It is not an exhaustive treatment of the topic, but one that aims to rebut standing — and largely unexamined - assumptions that deep systematic differences rule out Kant's drawing in substantive ways on Stoic moral psychology. To this end, my argument works first from the top down, and then from the ground up: $\$ 2$ argues that the standing assumptions are unfounded, and sets out an alternative view of the relevant systematic considerations; $\$ \$ 3-4$ work up from the textual details of Kant and his Stoic sources, to show how those details cohere with my systematic claims, and support the thesis that Kant accepts, on his own terms, the monistic principles of Stoic moral psychology.

Kant's sources distinguish the pathe that have the characteristic phenomenology of assailment from the dispositional forms of corruption that we nurse and sustain through habits of thought. The latter are the self-inflicted "diseases of the mind" — morbi animi — on which, as I argue in $\$ 3$, Kant models his account of the "passions" or Leidenschaften. Now, Kant quite obviously understands the passions to require the resources of a rational mind: he makes this point in various ways - above all deeming them "without exception evil [böse]" (Anth 7:267), or culpably bad. ${ }^{7}$ And he elaborates this point in ways that plainly allude to Stoic sources. That side of his picture straightforwardly supports the thesis at hand. However, he never quite says the same of the "affects" (Affekten) that he also (albeit with signs of ambivalence) includes within the target of apathy. Indeed, he characterises affects as "childish" (MS 6:408), which may give the opposite impression: i.e. that they are not culpable, and therefore cannot be understood to require the resources of a rational mind. This impression is reinforced by Kant's characterisation of their common phenomenology of assailment: they assault us in such a way that may seem to require the theoretical conclusion that they issue from some non-rational source. If all this were the case, we would have to conclude that Kant would have no coherent commitment to a

\footnotetext{
${ }^{7}$ See Kant's distinction between böse and $\ddot{u} b e l$ (KpV 5:60).
} 
monistic psychology in the Stoic tradition. In \$4 I argue that Kant's account of affects is not a counterexample to the thesis at hand.

Some further remarks on the scope of inquiry, and terminology, are in order. I began by noting Kant's endorsement of the Stoic principle of apathy: this is a paper, principally, about the targets of that duty. I do not follow the growing practice of inquiring about Kant's view of "the emotions": for it is not clear what Kant would take "emotion" to be. He speaks instead of "affects" (Affekten), various kinds of feelings (Gefïble), "passions" (Leidenschaften), and "inclinations" (Neigungen). When he speaks of Rührungen and Gemüthsbewegungen - terms that can sometimes be appropriately rendered "emotion" in English — he often has in mind something synonymous with Affekt, or closely bound up with it (see e.g. Anth 7:266, KU 5:272, and MS 6:408). But only some of the items in this broad tapestry of terms refer to mental states that we would naturally call "emotions"; moreover, the considerable controversy, in contemporary philosophy, about the nature of emotion should engender caution in inquiring after Kant's account of it. Notably, the same worry does not apply when we ask about Kant's engagement with the Stoic theory of pathe, since he would have thought about what that term meant: inquiry can then be pinpointed in principled ways, starting by considering what Kant took the target of the duty of apathy to be. That is the principle that guides my work here. Further, since Kant himself notes that apathy cannot plausibly be understood as a cultivated insensibility tout court (MS 6:408), we should recognise that the targets of apathy are members of broader class for which we may need a blanket term. I adopt "affections" as the term for the general sort of mental state at issue. ${ }^{8}$

The terminological complexity on the side of Kant's texts is more than matched, unfortunately, by the Latin texts from which he chiefly drew his understanding of the Stoic theory of affections. Notably, Cicero and Seneca render the central Greek term — pathos differently. The following table sets out the primary terms, for ease of reference; naturally I will be explaining the table's terms and arguing for its implicit claims about Kant's relation to his Stoic sources in the course of the paper.

\footnotetext{
8 "Affections" is a label for a range of psychic states and conditions that intuitively share some family resemblance; the term does not bear particular substantive weight in my account, which is concerned with the targets of apathy. Affections not within the target of apathy include: the feelings for the beautiful and the sublime, and the feeling of respect, on the side of Kant; and the eupatheiai, on the side of the Stoics. This list is not exhaustive, but further discussion is another topic.
} 
Table 1.

\begin{tabular}{|c|c|c|}
\hline \multicolumn{3}{|c|}{ TARGETS OF APATHY } \\
\hline \multirow{4}{*}{$\begin{array}{l}u \\
1 \\
0 \\
\text { H } \\
\text { in }\end{array}$} & E P I S O D I C & DISPOSITION AL \\
\hline & pathos $=$ & "disease of mind" = morbus animi \\
\hline & perturbatio (Cicero) & "infirmity" = aegrotatio \\
\hline & adjectus (Seneca) & $\begin{array}{l}\text { Cicero deems the difference between morbi and } \\
\text { eegrotationes "only theoretical" (TD 4.29). }\end{array}$ \\
\hline$\frac{n}{\mathrm{Z}}$ & "affect" (Affekt) & "passion" (Leidenschaft) \\
\hline
\end{tabular}

2. Systematic issues

We begin with the received view that deep systematic differences rule out supposing that Kant draws anything more than rhetoric from the Stoics. A paradigmatic expression of the received view is Jerome Schneewind's (1996) "Kant and Stoic Ethics", originally published in the influential volume Kant, Aristotle, and the Stoics; the fact that it was the only chapter in that volume dedicated to Kant's relation to the Stoics may partly account for the lack of attention the topic has received in the quarter-century since. Two kinds of systematic differences invoked by the received view will be considered: Kant's metaphysical dualism and his threefold faculty psychology.

\subsection{Metaphysical dualism}

Schneewind claims that, for Kant, desires are for the most part the ultimate sources of our reasons: "although we act for reasons, the sources of our reasons are not usually themselves reasons, or even rational. They are desires; and we do not choose our basic desires" $(2010,289)$. Desires are understood to be natural in a sense that is meant to contrast with rational: "For Kant [...] desires are non-rational causal forces" (289). Desires figure in the causal order of material nature; and yet they cannot make us do things, because we are rational beings, imputable persons. They are the sources of our reasons only if we freely take them to be such. Naturally, we might wonder what it means to take a desire, so conceived, as a reason. ${ }^{9}$ But Schneewind supposes that we need this conception of desire to anchor practical thought in the world: without it, practical reason could not yield "specific directives" for action (290). For Schneewind, any philosophical

\footnotetext{
${ }^{9}$ See, relatedly, Boyle (2016) on the "interaction problem".
} 
account of "the eruption of pure rationality into the causal order" must acknowledge human contingency, both in the species and in individuals; and this is done by recognising desires as given facts about that causal order, as a kind of "material" that gets worked up by practical thought (290). "The natural disarray of the passions and desires is a given in Kant's ethics, as the content of sensation is in the theoretical philosophy" (290).

Schneewind does not directly address how these remarks bear on his view of Kant's relation to Stoic ethics, since he goes on to suggest that Leibniz served as a proxy Stoic for Kant (292-3) - an unnecessary proposal, as we know that Kant read Seneca and other Stoic sources closely. But the dots are not hard to connect: the conception of desire at issue is offered as a humanising move - our desires are brute facts about us as denizens of the natural order; we can take them as reasons for action (or not), and thereby incorporate them into our maxims (or not); but they simply happen to us. We are dependent creatures with needs, and our desires are marks of this dependency. To suppose, with the Stoics, that desires are expressions of our rationality is to presume that they may be subject to rational control; this might invite a conception of moral progress as asserting such control over our desires, so that they are ultimately extirpated in some transcendence of our creaturely neediness.

Indeed, in the second Critique, Kant praises the Stoics for appreciating the rational basis of morality, but worries that their way of doing so results in a view of moral progress that "strained the moral capacity of the buman being" by locating the standard of virtue "under the name of a sage, far beyond all the limits" of human nature (KpV 5:127). But he does not appear to have entirely retained this view of Stoic ethics: for, when he later claims in the Metaphysics of Morals that "virtue necessarily presupposes apathy", he makes a point of saying that it is a poor understanding of that Stoic idea to think it lies in some absence of feeling or creaturely affections (MS 6:408). Moreover, the argument of the second Critique aims to establish the basis of morality in pure reason alone; and only once this is established does Kant begin to incorporate, into his account of morality, creaturely facts about us - a transition that begins with his discussion of the moral feeling of respect (from KpV 5:71). It is far from obvious that the relevant creaturely facts about us must be understood to be brutely natural, in distinction from what is rational, as Schneewind conceives of human desire. (The point quite obviously does not hold for respect.) Indeed, Kant simply does not subscribe to the view that human desires are "non-rational causal forces"; but before I make that case, let us consider a similarly mistaken interpretation of Kant on "the passions".

Martha Nussbaum claims that "the central difference between Kant and the Stoics" against a background of shared commitments about the rational basis of morality — lies in their 
respective accounts of "the passions" $(1997,17)$. How does she understand this divergence? She takes "the passions" to be given facts about human beings - dispensations we have in virtue of how we have been constituted by nature, rather than what we have made of ourselves through culture: "Kant appeared throughout his career to conceive of the passions, including aggression, as natural and precultural, and not removable from human nature” (19). ${ }^{10}$ She bases this view on a remark from "Towards Perpetual Peace", rendered thus: "War [...] does not require any particular kind of motivation, for it seems to be ingrained [gepfropff] in human nature" (Nussbaum 1997, 18; quoting a translation of Kant, 8:365). But Kant does not mean that aggression is worked into us in the way we are created. Rather, he says that war - and presumably also the aggression that leads to it - scheint auf die menschliche Natur gepfropft zu sein, "appears to be grafted onto human nature". This is not a fussy point of translation: the grafting metaphor is one of Kant's favourites ${ }^{11}$ and here the point is quite plainly that warlike aggression is not given in the constitution of the human being. We can see this if we recall Kant's claim that "passions [Leidenschaften] are [...] without exception evil [böse]" (Anth 7:267). If Nussbaum were right, the upshot would be that we are created evil. But this is obviously not the case for Kant (or the Stoics): we ourselves must be the source of any imputable badness, or evil. We see this reflected in the premise of Kant's account of radical evil: namely that we are created with an “original predisposition to good" (Rel 6:26) — we are endowed so that we are predisposed to act in appropriate ways, i.e. in ways that promote the completion of our essentially rational nature. ${ }^{12}$ Radical evil is the corruption of this original predisposition (see 6:43), which Kant claims can be traced to "the first manifestation of the exercise of freedom in the human being" (6:38). Kant likens this corruption to the preparation of the rootstock (the original predisposition) so that myriad forms of human badness "can be grafted" onto it (6:26-7) — among which he mentions certain inclinations, plainly having in mind the categorically evil sort of inclination, i.e. "passions". 13

These interpreters share the supposition that certain affections - "desires" (Schneewind) and "the passions" (Nussbaum) — must be natural in a sense that is meant to contrast with what is rational: they are given facts about how we are (and thereby features of the

\footnotetext{
${ }^{10}$ Nussbaum never makes explicit what she takes "the passions" to refer to in Kant; I assume she means the Leidenschaften, as this is how the term is usually rendered in English translations.

${ }^{11}$ As for Seneca, too: see Ep (112.2) — indeed, Kant likely draws his use of the metaphor from Seneca. In both, the metaphor is used for any imputable quality of character.

${ }^{12}$ On the Stoic origins of this premise see Merritt (2021).

${ }^{13}$ Nussbaum also assumes that Kantian passions are "natural" in a sense meant to contrast with "social" or "cultural": but Kant takes passions to be expressions of (corrupted) sociality (Anth 7:268) — a point emphasised by Wood (1999).
} 
causal order of material nature), rather than the expressions of the rationality of imputable persons. I have indicated, in a schematic way, why this cannot be the correct way to interpret Kant's conception of passions (Leidenschaften). But some may doubt that the same point should be made against Schneewind's interpretation of Kant's conception of desire. A likely protest is to point to the evident desires of non-rational animals and pre-rational human beings. But the salient issue is how we understand the difference that rationality makes to human mentality, not whether we attribute desires and emotions to non-rational animals and pre-rational human beings. Schneewind recognises that desires can only be sources of reasons for acting if we take them to be such; yet he also assumes that, by Kant's lights, desires themselves arise in us independently of rationality, or any such "taking" condition. I think this is neither obvious nor true. My point is more straightforwardly made with regard to inclination, so let me start there.

2.2 Metaphysical dualism does not entail the non-rationality of inclinations and desires Kant consistently explains inclination as "habitual desire" (babituelle Begierde, see e.g. Anth 7:251, 265; MS 6:212; Rel 6:28). The desire is habitual because it has been repeatedly gratified in a certain manner. These acts of gratification, in human beings who have come into the use of reason, express commitment to a maxim: to satisfy this sort of need or longing in this sort of way, with this sort of object. Now, Kant also explains inclination as "sensible desire that serves the subject as a rule (habit)" (Anth 7:265): they are expressions of commitment to a view about how to go on in certain circumstances, even if one does not reflect on this rule and its wisdom. So the inclination itself, in an adult human being, is an expression of rationality. This is not to deny that non-rational animals and pre-rational children have habitual desires, or inclinations: they quite plainly do. But lacking rationality, their inclinations could not themselves be expressions of a view about what is a reason for doing what.

The standard objection to this picture should now be familiar: inclinations assail us, unbidden and thus independently of the will. Running this line of objection, Tamar Schapiro observes that we do not hold ourselves responsible for our inclinations "in the same way that we hold ourselves responsible for acting on them" (2009, 33). True. For indeed, we still might not act on a given inclination. But we are responsible for our inclinations inasmuch as they are the result of our having done certain things, habitually, in the only way that an imputable human being can do things — namely, with (typically tacit) commitment to maxims. Inclinations may assail us unbidden, and some of them may be unwanted; but they themselves emerge from 
accretions of prior assent. ${ }^{14}$ So we are responsible just for having them, albeit not quite in the same way as we would be for acting on them. ${ }^{15}$

The standard by which affections count as rational will be further specified in $§ 4$. For now, the key consideration is this: When we consider the rationality of inclinations and desires, we have in mind what is "rational" in the sense of requiring the resources of a rational mind, not what is "rational" in the sense of meeting some normative standard of rationality, such as wisdom or virtue. ${ }^{16}$ When interpreters assume that Kant's metaphysical dualism entails psychological dualism, they tend to lose sight of this crucial distinction between two senses of "rational". ${ }^{17}$

Kant's metaphysical dualism features prominently in the ethical works of the earlier critical period, especially the Groundwork, where he is particularly at pains to argue for the rational basis of morality. ${ }^{18}$ This is what sets up the conflict between duty and inclination as two distinct kinds of incentive on action. This division suggests a picture of the human being as straddling two worlds, subject to one's inclinations as an entity in the domain of nature, and yet autonomously determining one's own will as a person in the kingdom of ends. Morality is then pictured as a conflict between these metaphysically distinct aspects of one's nature, rather than as a conflict entirely within one's rationality. The earliest misunderstandings of the Groundwork stem from a picture of this sort, attributing to Kant the idea that one only acts freely when one acts out of respect for the moral law, and otherwise acts like anything else in the domain of nature, directly impelled by "non-rational causal forces" as desires might be taken to be. ${ }^{19}$

Kant clarifies his position in later works, particularly the Religion, with what has come to be known, following Allison (1990), as the incorporation thesis: "the freedom of the power of choice has the characteristic, entirely peculiar to it, that it cannot be determined to action through any incentive except so far as the human being has incorporated it into his maxim" (Rel 6:23-4). The human being is not free only when he acts out of respect for the moral law, and otherwise

\footnotetext{
14 See Wilson (2016) and Wood $(2018,100)$ for similar accounts of inclination. One difference between them is that Wilson does not question the received view of Kant as a psychological dualist, while in a related context Wood (2011, 76-7) does.

${ }^{15}$ For further discussion, see Merritt (forthcoming).

${ }^{16}$ See, relatedly, Inwood (2005, 43-4).

${ }^{17}$ E.g. Sherman $(2013,760)$ claims that Kant takes inclinations to be non-rational or "rooted in our sensuous natures and as such impel us from a source other than autonomous practical reason and its laws". Of course, acting on inclination is not acting from respect for the moral law: nevertheless, inclination is not, simply for that, "non-rational".

${ }^{18}$ See Baron $(1995,203-4)$ on how this aim of the Groundwork invites misunderstanding of Kant's moralpsychological commitments.

${ }^{19}$ It then becomes inconceivable how one could freely violate the moral law; the objection is usually traced to Kant's contemporary Carl Leonhard Reinhold — for discussion see Allison (1990, 133-6).
} 
directly impelled by sensible desires. For imputable personhood arises with coming into the use of one's reason, not with having developed one's rationality, and thus the will, according to a normative standard of perfection. Allison — rightly, in my view — presents the incorporation thesis as the practical manifestation of Kant's apperception principle $(1990,40)$, that "the 'I think' must be able to accompany all of my representations" (B131-2). Apperception is the selfconsciousness internal to thought: it is not an awareness of oneself as an object, but a grip on oneself as the source of one's own thoughts. Allison's point about the incorporation thesis, then, is that intentional action is the expression of this same self-consciousness - now a grip on oneself as the source of one's own actions. Thus we act always as imputable persons, even when we act on sensuous inclination or desire.

On one interpretation of the incorporation thesis, the idea is simply that inclinations provide motives or reasons for acting only if we take them to be so: the items that we "incorporate" into our maxims would still understood as essentially non-rational, arising in us independently of rational thought. I have been arguing that this cannot be the case for inclination, regardless of the incorporation thesis: for inclinations are habitual desires, built up from accretions of assent. Though they may assail us, they are still not something that simply happens to us. (We have done a lot to make them "happen".) Yet not all our desires are habitual: some might be new and fresh, some might assail us one-off. However, even one-off desires involve seeing things in a certain light — as worth going for — which requires the resources of rationality. That's what it means for them to be yours, rather than something that happens to you. Hence Kant explains desire (evidently thinking of desire in us, human beings who have come into the use of reason) as "the self-determination of a subject's power through the representation of something in the future as an effect of this representation" (Anth 7:251). ${ }^{20}$

Let me recap. Many commentators tacitly assume that Kant's commitment to metaphysical dualism entails a commitment to psychological dualism, the view that there are separate rational and non-rational parts or aspects of human mentality. The incorporation thesis makes clear, at the very least, that imputable persons choose freely even when they take sensuous inclination or desire as a reason for acting. So understood, the incorporation thesis may still allow for a dualist view of human mentality: desires would remain "non-rational causal forces" and only provide reasons for action if we take them to be so. But this might not be the case, I propose, if the incorporation thesis is the practical extension of the apperception principle. More generally, when we consider whether to accept the idea that desires are the product of rational thought, we do not need to stumble over the observation that non-rational animals and

${ }^{20}$ For a related view of how Kant takes desires to be rational, see Wood $(2011,76-7)$. 
pre-rational children presumably have desires. What matters, rather, is the difference that reason makes to human mentality. And if that difference is understood in terms of apperception, the upshot is plausibly that the coming online of apperceptive thought thoroughly transforms human mentality. There would then be no non-rational elements our mentality, once we come into the use of our reason. Now let me lay out some initial textual evidence for taking this view of Kant's systematic commitments.

In the opening section of the Anthropology, Kant considers what "raises" the human being "above all other living beings on earth", which for him means other animals. ${ }^{21}$ The schematic answer lies in the essentially rational nature of the human being, which Kant proposes consists fundamentally in " $[\mathrm{t}]$ he fact that the human being can have the ' $\mathrm{I}$ ' in his representations" or the faculty of apperception (Anth $\$ 1,7: 127) .{ }^{22}$ He presents the coming online of apperceptive thought as a watershed moment in human development: this transformation makes one a person, the imputable source of one's own actions (7:127). Although the substance of this claim is familiar - it is of a piece with the Kantian analysis of intentional action as the expression of commitment to maxims - the developmental context is unusual. But it indicates that, by Kant's own lights, coming into the use of one's reason transforms human mentality in a thoroughgoing way. If so, then desires and the other states I am calling "affections" are products of our rationality. I will return to this systematic point in relation to recent scholarship in $\$ 2.3$; here I am simply adducing the systematic considerations we need to have in mind if we are to query Kant's relation to Stoic moral psychology in a productive way.

\subsection{Kant's threefold faculty psychology}

Another view to consider is Nancy Sherman's denial that "Kant's frequent use of Stoic rhetoric" amounts to any "genuine endorsement of the Stoic radical position on the emotions" (1997, 116). She says this in the context of arguing, more generally, that emotions play a necessary role in virtue: on this central theme of contemporary virtue ethics, Sherman takes Kant to be philosophically aligned with Aristotle (119). For Sherman, Kant's "view, essentially, is that emotions are sensations. They are a psychic quality of feeling" (178). She then points to Kant's explanation of feeling as "the capacity for having pleasure or displeasure in a representation", and to his view that pleasure and pain are "merely subjective $[. .$.$] and contain no relation at all to an$

\footnotetext{
${ }^{21}$ See Kant's account of life at $\mathrm{KpV}$ (5:9n), which incidentally implies his endorsement of the Stoic view that animals, but not plants, are alive (see e.g. Cicero ND 2.120-121).

${ }^{22}$ Kant refers here to the faculty of apperception as "understanding" (7:127): but he is plainly using the latter term in his broad sense, where it refers to the intellect as such - a designation for which he is equally happy to deploy the term "reason" (compare, e.g., A130-1/B169 with A835/B863).
} 
object for a possible cognition of it (or even cognition of our condition)" (MS 6:211-2). But Sherman provides no textual or reconstructive argument for the assumption that Kant takes "emotions" to be feelings; she instead takes that as given and then draws on the above remark to conclude that he cannot share the Stoic view of the pathe as a kind of judgment, and their ensuing conception of moral development as a matter of correcting evaluative confusion (1997, 103-6, 118). ${ }^{23}$ For Sherman, "Kant inherits the Stoic rant against ordinary emotions, but discards the interesting cognitivist moral psychology that undergirds the Stoic account of moral reform" $(2013,760)$.

I've already raised concerns about inquiring after Kant's view of "the emotions"; nevertheless, Sherman's remarks raise good questions about how Kant's threefold faculty distinction should bear on any interpretation of his theory of affections. Prima facie, his threefold division might seem to raise particular difficulties for my thesis that Kant endorses psychological monism. However, this is not the case. The three faculties at issue are the "feeling of pleasure and pain", the "faculty of desire" and the "faculty of cognition": Kant presents this threefold division in both Introductions to the Critique of Judgment (KU 5:177, 196-8; 20:206, 245), and in that context emphasises the non-cognitive quality of feeling (KU 5:205-6), as he does in the passage Sherman mentions (MS 6:211-2). However, it should be noted that none of these faculties is reason. Relatedly, we have grounds to suppose that the threefold division holds for non-rational and pre-rational ways of being minded, as well: the point should be obvious for feeling and desire, and it is highly plausible — not just as an independent claim, but as an interpretive claim about Kant (see McLear 2020) — that non-rational animals and pre-rational human beings must have some sort of cognition, in order to be agents at all (albeit not imputable ones). So the fact that Kant takes there to be three fundamental faculties of the mind does not entail that he takes some of these faculties to be rational and some non-rational. Indeed, the threefold division does not itself bear on the salient question about the difference that rationality makes to human mindedness.

In order to explain in positive terms how I understand the relation between the threefold faculty division and the thesis of psychological monism, it will help first to consider Alix Cohen's recent account of Kantian "emotions" - by which she means "the numerous, distinct states that Kant calls 'feeling', 'affect', 'passion', 'inclination', 'desire', and even 'instinct”' (2020, 432), more or less the same broad class that I call "affections". Her core thesis is that "emotions" are essentially feelings by Kant's lights: however, as she indicates, this does not mean that they are pure

\footnotetext{
${ }^{23}$ Sherman's view that "emotions" are feelings and therefore non-cognitive gives rise to a telling struggle over how to handle Kant's view of moral feeling, especially respect (1997, 175-81).
} 
feelings. Cohen reasonably takes the threefold faculty division to mark irreducible functional distinctions, and argues that feelings are "about ourselves", which is "precisely what distinguishes them from cognitive and conative states, which are about the world" $(2020,444)$. Thus even though passions and inclinations are classified by Kant as desires (not feelings), presumably by Cohen's lights this could be explained by supposing that the feeling element that they must involve is connected with a desire element. For Cohen reasonably observes that "feelings, like all our other mental states, are always connected with both cognitive and volitional states as part of the ongoing activity of the mind" (433). As an example to illustrate her point, we might take two negatively valenced mental states that we could recognise as "emotions": remorse and dread. Although both are disagreeable or painful, they are so in light of different kinds of considerations: to begin with, remorse has to do with the past, dread with the future. In claiming that "emotions" are essentially feelings, she supposes that they are modes of pleasure and pain, with optional trappings from cognition and desire to give them "derived intentionality" (433-9).

I would acknowledge that we cannot have an affection without feeling, but deny that affections are essentially feelings — if by that we mean a "psychic quality" of pleasure and pain, with optional connections to cognitions and desires. Rather, the affections that we have ordinary names for — things like dread, remorse, anger, fear and so on — are plausibly understood as complexes of feeling, cognition, and desire. By the lights of Kant's threefold faculty psychology, they can be understood as felt self-manifestations bound up with taking things to be a certain way, where that "taking" can be cognitive or conative or both. ${ }^{24}$ That is the approach I will take to Kant's view of affections in the remainder of the paper.

With this in mind, let us return to Anthropology $\$ 1$, the passage that speaks of acquiring apperceptive self-consciousness as a watershed moment in human development. Kant does not take the acquisition of rudimentary language to be the essential mark of this rationality. Rather, he maintains, "the child who can already speak fairly fluently" does not yet begin "to talk by means of 'I"' until sometime later (7:127):

When he starts to speak by means of 'I' a light seems to dawn on him as it were, and from that day on he never again returns to his former way of speaking. — Before he merely felt himself, now he thinks himself. (7:127)

The remark suggests that pre-rational children are manifest to themselves through feeling. Certainly the passage does not say that we are no longer manifest to ourselves through feeling once we acquire the resources of apperceptive thought. The point is rather that we are no longer

\footnotetext{
${ }^{24}$ In Stoicism, such takings are typically both cognitive and conative, as a referee points out.
} 
manifest to ourselves merely through feeling. Further, the passage does not speak as if this transition to personhood were a matter of acquiring the use of an additional faculty, one we might call "reason". The spirit of the passage rather suggests that the activation of this faculty, with the coming online of apperceptive self-consciousness, transforms the entire mentality of the human being. After this transformation we may still be manifest to ourselves through feeling, only now in a way that requires the resources of rationality.

A growing body of recent work argues that Kant thinks of reason as a faculty that transforms the powers and dispositions that we plausibly share with pre-rational humans and non-rational animals. ${ }^{25}$ A thoroughgoing version of such a view would be a form of psychological monism, although proponents of this line have not generally considered the issue in such terms. However, Schapiro (2009), representative of a contrary line of interpretation, does, urging the rejection of psychological monism on the grounds that it cannot, she supposes, make sense of our being assailed by affections, and their not being subject to rational control. ${ }^{26}$ Varden $(2020,37)$ adduces similar considerations in a discussion of love and sexual attraction: although such affections are appropriately developed through "self-reflective consciousness and abstract conceptual reasoning powers", they retain their "core aspects" independent of rationality, on the grounds that we do not come into them (or go out of them) through any kind of rational choice or abstract reasoning. However, the point that I am aiming to make about the rationality of affections does not hinge on a point about rational control; affections are expressions of apperceptive self-consciousness, like anything in our mentality, and thus involve rational "takings". Now, a full account of the issues raised by this sketch of opposing systematic approaches lies beyond my scope here; I am concerned with historical questions about the roots of Kant's accounts of affect and passion in Stoic (and therefore monistic) psychology. But that historical investigation will support the first kind of systematic position.

I've had two aims in this section. One is to resist the assumption that systematic differences rule out Kant's drawing anything more than rhetoric from the Stoic account of affections. The other has been to outline how I understand the relevant systematic issues. Now I will switch tack, and work up from the details of Kant's account of affections, examined in relation to his Stoic sources. I'll argue that Kant understands both passions (Leidenschaften) and affects (Afftekten) as targets of the duty of apathy, in a manner that broadly aligns with the monistic principles of Stoic psychology.

\section{The targets of apathy}

${ }^{25}$ E.g. Boyle (2016), DeWitt (2018), Schafer (2020) — this list is not exhaustive.

${ }^{26}$ Again, for further elaboration see Merritt (forthcoming). 
At the outset of this paper, I noted Kant's endorsement of apathy in the Anthropology and the Metaphysics of Morals - two texts in the period under consideration, when Kant is reported to have been closely studying Seneca. But I would like to begin with a remark from an earlier text - not a published work, but Latin notes for an oration likely delivered at the conclusion of his rectorship of the University of Königsberg in 1786. ${ }^{27}$ There he commends apathy, "insofar as it consists in freedom from those mental propensities properly called passions [passiones]"; but passions, he continues, should be distinguished from "those inward motions of the mind that are called affects [affectus]" — for inasmuch as some affects (he mentions joy, indignation, and admiration) "can be healthful", they should not be taken as targets of apathy (15:940). Ultimately, I do not think there is a vast distance between this remark and those in later texts, where Kant takes affects and passions (Affekten and Leidenschaften) alike to be targets of apathy: for he retains some version of the thought that affects "can be healthful" — though we will need to postpone examination of this point to the final stretch of the paper.

At any rate, by the late 1790s, Kant indicates in his published works that he takes affects and passions alike to be the targets of apathy. When Kant, as previously noted, endorses apathy as "an entirely correct and sublime moral principle of the Stoic school", he glosses it as the view that "the wise person must never be in a state of affect [niemals im Affect]" (Anth 7:253). He moreover claims in this context that being subject to affects and passions alike is "always illness of mind" because both "shut out the rule of reason [Herrschaft der Vernunft]" (7:251). Likewise, when Kant proposes that virtue requires "in the first place, mastery over oneself [Herrschaft über sich selbst]" (MS 6:407) and therefore "presupposes apathy" (MS 6:408), he includes both affects and passions within the target. Some may find in these remarks suggestions of a background commitment to a dualist psychology, where apathy would be commended as that condition in which reason rules over the non-rational elements of our mentality that would otherwise usurp control. However such an interpretation would not take on board the crucial distinction between what is "rational" in the sense of requiring the resources of a rational mind, versus what is "rational" in the sense of meeting a normative standard of rationality. A mind that has shut out the "rule of reason" - and is thereby conceived as "diseased" or in defective condition — is simply not rational in this stronger normative sense. Nothing in these remarks entails the dualist view that affects and passions are what we get when a distinct non-rational part of the soul takes over. $^{28}$

\footnotetext{
27 “On the Philosophers' Medicine of the Body"; see Kant (2007, 182).

${ }^{28}$ Cf. Kant's lectures on anthropology (Friedländer [1775-6] 25:616-7), where he appears not yet to have his mature view.
} 
3.1 Outline of Kant's distinction between affects and passions

Kant distinguishes affects and passions in terms of his threefold faculty psychology: affects are expressions of feeling, passions of the faculty of desire. ${ }^{29}$ As I have previously noted, passions are a species of inclination (Neigung), which Kant consistently explains as "habitual desire". An illuminating point of entry into Kant's distinction between affect and passion can be found in this remark about shame:

Shame is anguish that comes from the worried contempt of a person who is present and, as such, it is an affect. Moreover, a person can also feel ashamed without the presence of the person before whom he is ashamed; however, then it is not an affect but, like grief, a passion for tormenting oneself persistently with contempt, but in vain; shame, on the other hand, as an affect, must occur suddenly. (Anth 7:255)

The remark, which displays several important features of Kant's distinction, principally brings out the immediacy of affect. Likewise, Kant identifies anger and shame as affects, explaining both as "suddenly aroused feelings of something ill [ein Übel] in the form of an insult" (7:260) - which, in the case of shame, is censure. Affects, as such, are sudden and surprising: e.g. shame involves some shock at having been caught out.

Now, Kant in this passage distinguishes between shame as an affect and something else that he conceives as a kind of passionate shame. Here it is appropriate to observe that Stoics classify pathè under four genera: pleasure (bèdonê), distress (lupê), appetite (epithumia), and fear (phobos). That division runs on two axes: one divides positively from negatively valenced pathé, the other divides pathe that arise from belief about present goods and bads from those that arise from beliefs about impending goods and bads. ${ }^{30}$ Kant's account of shame, as an affect, aligns with the Stoic classification of distress: i.e. a negatively valenced pathos arising from a belief about a present bad thing. We might then wonder if the related "passion for tormenting oneself persistently with contempt" would align with the Stoic classification of fear, i.e. a negatively valenced pathos arising from a belief about an impending bad thing. No: this passionate shame is not expression of fear about impending censure from others. Rather, Kant's thought is that this passionate person torments himself more or less under his own steam. Thus the important point about passions is not the future-orientation they may have as a species of inclination (and

\footnotetext{
${ }^{29}$ There are three main passages in Kant's published works devoted to the distinction between affects and passions (Anth \$§73-4 7:251-2; MS 6:407-8; KU 5:272n); my paraphrased claims about Kant's affectpassion distinction refer to these passages, which are fully consistent with each other.

${ }^{30}$ Stob 2.88.15; Cicero TD (3.24).
} 
thereby as expressions of desire); rather it is that passions are internally sustained movements of thought — and thereby express entrenched practical commitments.

We see this last point illustrated through Kant's distinction between anger and hatred: "What the affect of anger does not accomplish quickly, it does not do at all; and it forgets easily. But the passion of hatred takes its time, in order to root itself deeply and think about its opponent" (Anth 7:252). Kant is not saying that anger expresses no practical commitment: the point rather is that its practical commitment is not entrenched. Kant consistently remarks that surprisingness or suddenness is essential to affect: "Affect is surprise through sensation whereby the mind's composure (animus sui compos) is suspended" (7:252). Affect is "precipitate or rash [jäh oder jach] (animus praeceps)" (MS 6:407) — plausibly alluding to Seneca's characterising pathè as movements that pitch the mind headlong (praecipitat, Ira 1.7.4). Affects seize us, blocking ready access to reflection (Überlegung), which Kant explains in this context as the consideration of whether one should "give himself up" to the affect "or refuse it" (Anth 7:251; see also 6:407). Passions, by contrast, "can be paired with the calmest reflection" and are not thoughtless or indeliberate (unbesonnen) like affects (7:265). Kant makes quite explicit that passions express commitment to maxims, and thus are "rational" on those terms:

Passion always presupposes a maxim on the part of the subject, to act according to an end prescribed to him by his inclination. Passion is therefore always connected with his reason, and one can no more attribute passion to mere animals than to pure rational beings. (7:266)

This remark, which openly alludes to the Stoic theory of affections, raises some questions. For if the point is to draw a contrast with affect, it may give us the impression that affects are not expressions of our rationality: they simply come over us, as some kind of non-rational causal force. This impression might appear to be reinforced by Kant's vivid analogy: "Affect works like water that breaks through a dam; passion, like a river that digs itself deeper and deeper into its bed" (7:252). If Kant means here that affects break in upon rational mindedness from without, then he wouldn't be drawing coherently on Stoic moral psychology; but in $\$ 4$, we will see why that conclusion would be wrong. For now we can consider the point about passion as it is stated. Passions are internally sustained through habits of thought that gradually etch ever deeper channels along which one's thinking is compelled to run. They are not sudden or surprising, like affects, but deep-seated expressions of practical commitment, and thereby require the resources of a rational mind.

I have explained why Kant's distinction between affect and passion should not be confused with a distinction that Stoics draw within the class of pathe. Instead, as we are about to 
see, Kant's distinction aligns with another division in the broader Stoic theory of affections, one between pathe and the "mental diseases" that develop from them. ${ }^{31}$

\subsection{The source of Kant's affect-passion distinction in Cicero and Seneca}

Cicero believes that the most literal Latin rendering of the Greek pathos would be morbus or "disease", and complains that the translation would strain normal Latin usage, since only the pathe in the class of distress (lupe) can plausibly be likened to diseases (TD 3.7, 3.22). He is wrong about the Greek: the standard Greek words for "disease" are nosos or nosema; pathos comes from paschein, to undergo, suffer, or be affected - and only refers to disease in specialised medical contexts. ${ }^{32}$ But the point leads Cicero to distinguish pathos in the strict sense — "disturbance" or perturbatio in his Latin - from diseases and infirmities of the mind, morbi and aegrotationes (see Table 1$).{ }^{33}$ Cicero explains the distinction thus:

The point to be grasped, then, is that although pathos is turbulent and inconsistent, constantly in movement through shifts in belief, it sometimes happens that this simmering and agitation of mind becomes habitual [inveteraverit], settling into the veins and marrow, as it were. It is then that sicknesses and infirmities [morbus et aegrotatio] come into being, and also the aversions which are their contraries. (TD $4.24^{34}$ )

So, for example, Cicero quotes a Stoic definition of hatred as "inveterate anger" (ira inveterata, 4.21): $:^{35}$ the point is not that the hater runs around in a constant rage, but rather that some dimension of his practical outlook has been shaped by a habitual anger towards someone, or some group of people. We can see the same point reflected in Kant's distinction between the affect of anger and the passion of hatred. Moreover, "inveterate anger" must be distinguished from irascibility, as a dispositional quickness to anger (at whatever target): for hatred is nursed on a particular object, as irascibility is not. ${ }^{36}$ Notably, however, Cicero does not liken the pathos to a

\footnotetext{
31 As Seidler $(1981,1115-8)$ also observes.

32 See also Inwood (1985, 127-8 and 291n3).

33 The morbus-aegrotatio distinction renders that between nosémata and arröstèmata noted in DL (7.115) and Stob (2.93). Like these sources, Cicero explains aegrotatio as "a sickness [morbum] accompanied by weakness" (TD 4.28); yet he takes the morbus-aegrotatio distinction to be "only theoretical" (4.29), presumably supposing that wherever there is comprehensive and chronic disease (i.e. morbus) there will follow general weakness (i.e. aegrotatio).

${ }^{34}$ Since Cicero explains that he translates the Greek pathos with perturbatio, I will use the Greek term throughout my discussion and quotation of Cicero. Hence I've substituted pathos for Graver's "emotion" (rendering perturbatio) in this quotation. Similar treatment will apply to Seneca, who translates pathos with adfectus instead. See Table 1.

${ }^{35}$ Likewise Seneca: "morbi are faults that have become ingrained [inveterata] and hard, like greed and ambition" (Ep 75.11).

${ }^{36}$ Cicero muddles the distinction between sentimental proclivities (e.g. irascibility) and aegrotationes (TD 4.27-8); however he signals that he is departing from his Stoic sources there. His confusion matters, since
} 
blow from without — as we might imagine with Kant's likening affect to water that breaks through a dam. Rather, Cicero likens pathe to liquids that ooze and shift about from within, gradually settling into a steady simmer, so that they may then seep nimbly into the channels that are meant to distribute nourishment, ultimately producing comprehensive sickness instead. In this way, Cicero's images direct us to think of both pathe and morbi animi as diseases that develop from within.

Plainly, the fact that morbi animi arise from habit does not make them any the less expressions of rationality: they settle in through the habitual movement of justificatory thought — an idea well expressed by Cicero's "veins and marrow" metaphor, inasmuch as justificatory thought is the lifeblood of rationality. This point is made clearer as Cicero continues:

They define infirmity [aegrotationem] of mind as 'a vigorous opining that some object is worthy of pursuit which is in fact not worthy of pursuit, that opinion being deeply attached and rooted [insitam] in the mind'. [....] 'Opining' is when a person judges that he knows something which he does not in fact know. (TD 4.26)

Thus the remark suggests that pathos-aegrotatio pairs, such as anger and hatred, would share an axiological error — in that case, regarding the goodness of retaliation for perceived injury. The axiological error is simply "deeply attached and rooted" — indeed one could say "grafted", for insitam $^{37}$ — in the case of infirmity. Importantly, though, these affections both involve opining, and thus making a mistake about one's own epistemic condition — only with an infirmity, this misapprehension of oneself becomes a matter of standing disposition or character.

We find the same message in Seneca, more briefly set out, and with simpler terminology: his distinction is simply between pathos (adfectus is his Latin) and morbus animi. Morbi, he says, "bind [implicuerunt] the mind much more tightly" than any pathos (Ep 75.11). So it seems that the one is, again, simply more firmly fixed than the other. However, Seneca contextualises his account of morbus animi differently, explaining it as "a persistent judgment in a corrupted person [in pravo] that certain things are very much worth pursuing that in fact are only slightly worth pursuing" (75.11, my underscore). The phrase in pravo invokes the idea of natural development gone wrong - literally, the creature has come up crooked rather than straight. Thus Seneca suggests that a morbus is possible only in a person who is corrupted in some thoroughgoing way — which, as the broader discussion (Ep 75.10-14) indicates, is not necessarily the case with

irascibility could simply be a congenital feature of temperament, while hatred cannot: i.e. he risks losing his grip on the culpability of aegrotationes.

${ }^{37}$ Lewis and Short, s.v. insero. 
pathos. ${ }^{38}$ Yet this allows us to see how the morbi might be faulty in a special way - that is, in a way that goes beyond whatever way pathè are faulty and proper targets of apathy. For while both pathe and morbi involve the same kinds of evaluative confusion - taking to be good what is not in fact good, and so on - the morbi are expression of deep attachment to these mistakes. The mistakes will instead seem perfectly natural and appropriate, which makes morbi bad in their own special way.

At this point, we should be able to see in outline how Kant's distinction between affect and passion aligns with the Stoic distinction between pathè and morbi/aegrotationes. We will need to examine Kant's conception of affect more closely, to see if it could be compatible with the monistic principles of Stoic moral psychology (in \$4). But Kant’s conception of passion, just on its own, threatens no such counterexample. For Kant quite plainly tells us that passions are expressions of commitment to maxims. Any remaining doubts should be extinguished by Kant's deeming passions "without exception evil [böse]" (7:267): to call them böse is to take them to be imputable, and thus expressions of rationality. But we might wonder how seriously to take this remark. Why are passions necessarily böse? Although a full answer to this question would lead to issues tangential to our topic, a partial answer is appropriate to show, in a more determinate way, how Kant engages with Seneca. When Kant deems the passions categorically böse, he is thinking particularly of Seneca's hints about the special faultiness of morbi.

\subsection{The badness of passions}

For Seneca, as I just argued, the badness of morbi does not simply consist in their being expressions of evaluative confusion - for that much can be said of pathè as well, by Stoic lights. Their special faultiness lies rather in their being manifestations of deep attachment to these mistakes. This view is reflected in his remark that the "murkiness of our minds" as imperfectly rational beings is the source of "both the inevitability of our mistakes and our fondness for the mistakes that we make" (Ira 1.10.1). The pathe are expressions of a rational point of view; and Seneca's point, in effect, is that we are disposed to root them deeply through habitual movements of justificatory thought, forming the morbi. We are so prone because we are (imperfectly) rational — doing the things a rational being does, only badly. The morbi are thereby symptoms of a comprehensive corruption of reason. This is how Seneca comes to speak of

\footnotetext{
${ }^{38}$ Cicero accommodates such a point by distinguishing "sicknesses and infirmities" as comprehensive defects from their genus, "fault" or "defect" (vitium), which need not be comprehensive — just as a misshapen limb need be neither a reflection nor a source of poor overall health (TD 4.28-9).
} 
morbi as "faults that have become ingrained and incurable [inemendabilem]" (Ep 106.6; my emphasis).

Kant similarly thinks that passion tends to be "incurable because the sick person does not want to be cured": it is an "illness that abhors all medicine" (Anth 7:266). Curiously, the latter gloss attributes a sense of affinity to the passion itself: i.e. it's the passion that finds medicine abhorrent. This raises the question whether there is something else in us, apart from the passion — something that doesn't find all medicine abhorrent, as it were. This may seem like an absurd question; but it is one raised by the systematic issues we have been considering. Consider again the view that I attributed to Seneca in the previous paragraph. If we are rational through and through, then all of our particular faults might be expressions of a more fundamental corruption of rationality itself. That result raises a question about what resources an ordinary human being has to restore herself to health - i.e. to make herself good. And that is a problem for the Stoics, since their commitment to psychological monism is at least partly motivated by its resources to show, uncompromisingly, that we corrupt ourselves: therefore, it should lie fully within our power to undo what we have wrought, and make progress towards virtue (see e.g. Frede 1986, 98-9). No fault should be incurable, in other words. Yet Seneca speaks of morbi, and Kant of passions, as faults that have become incurable.

We cannot take up the question of how Seneca and Kant come to speak of incurable faults, except to register that the claim is largely rhetorical. The common point concerns the status of morbus animi (for Seneca) and passion (for Kant) as perversion: it is an outgrowth of rational activity, but in a corrupted person (a pravus, says Seneca). The passionate person is attached to these growths that, as it were, undermine his own health or bodily integrity - a point Kant makes by likening passions to chains that have grown together with one's limbs (Anth 7:267). Therefore, it will take some kind of fundamental reorientation to recognise it as the perversion that it is. I will not here examine how the Stoic tradition conceives of this reorientation. But Kant does not face quite the same problem, because he doesn't think that radical evil (i.e. the source of all human badness) can consist in a corruption of reason itself; rather, as I noted in $\$ 2.1$, he takes it to consist in a corruption of the "original predisposition to good" (Rel 6:43), which he conceives as an affective orientation, a sense of what is appropriate to one as a creature of a certain kind. That's how passions are expressions of radical evil: their special kind of badness lies in their air of naturalness, their being passed off as appropriate to one's kind - where radical evil consists in a perversion of this sense of what is thus appropriate. In outline, that is why Kant deems passions categorically evil (böse). Yet one aspect of this predisposition, he maintains, is incorruptible: the "predisposition to personality" — one's sense 
of what is appropriate to one as an imputable person $(6: 26,27-8)$. The upshot is not that our corruption fails to be comprehensive: Kant clearly thinks that it is. Rather the point is that we can never lose resources needed to recognise the passions as the perversions that they are - and find them, thereby, abhorrent.

Thus the special badness of Kantian passions, like the special badness of Stoic morbi, lies in our attachment to them: we nurse them through habits of thought, and find them fitting and appropriate, when they are not. As a result we are not normally moved to do anything about them: they do not register — at least not clearsightedly — as something in need of a cure. That's why they are deemed "incurable", though they are not, strictly speaking. And while there are subtle but important differences in how Kant and the Stoic tradition respectively understand human corruption, ${ }^{39}$ those differences do not bear on the question of Kant's commitment to psychological monism. Certainly Kant's account of the passions provides no counterexample to that thesis.

\section{Affects and psychological monism}

Now we turn to further specifics of Kant's account of affect (Affekt). My aim is to show why, despite possible appearances otherwise, it is not a counterexample to the thesis that Kant endorses psychological monism. I have mentioned that Kant's characterisation of the phenomenology of affects contributes to this impression, along with some signs of ambivalence about counting them as targets of the duty of apathy; but the most significant factor may lie in his remark that it is "not the intensity of a certain feeling [Gefühls] that constitutes the state of affect, but rather the lack of reflection" involved (Anth 7:254). On some accounts of what Kant means by "reflection" in this context, the point of the phenomenological characterisation is that affects seize rational mindedness from the outside: they are not themselves rational in any relevant sense. ${ }^{40}$

Let us begin, then, by looking more closely at Kant's remarks about reflection in his account of affect. In one of the passages where Kant explicitly includes affect within the target of apathy, he explains affect as "the feeling of a pleasure or displeasure in the subject's present state that does not let him rise to reflection (the representation by means of reason as to whether he should give himself up to it or refuse it [die Vernunftvorstellung, ob man sich ihm überlassen

\footnotetext{
${ }^{39}$ See Merritt (2021).

${ }^{40}$ Frierson (2017:250) argues that affects "bypass" rational faculties entirely; we cannot, as a result, have anything like a point of view on how things are and what to do when we are in the throes of affect. Although I took a somewhat similar line in Merritt (2018), I now think that appreciating the specific Senecan background of Kant's account of affect shows this interpretation to be false.
} 
oder weigern solle])" (7:251). It is not obvious what this definition means. Two things about it are relatively clear: that affect is a mode of feeling; and that the feeling involved is an obstacle to a kind of rational consideration that Kant calls "reflection". Kant presents "reflection" as some kind of consideration of whether to "give oneself up to" or to "refuse" something: but what, exactly? If there is already something that one feels, it is not obvious what it would mean to consider whether to give oneself up to, or to refuse, that feeling.

The solution lies in the lesson we drew from Kant's threefold faculty psychology in $\$ 2.3$ : namely, that our mental states are not typically "pure" feelings, or "pure" cognitions, or "pure" desires - rather the mental states that we can identify in a normal way are complexes of these. Affection, I suggested, can be understood as a felt self-manifestation bound up with taking things to be a certain way (cognitively or conatively, or both). The object of reflection - that which stands as something to "give oneself up to" or to "refuse" — is some such complex. To work through the solution, we can use Kant's own illustration, an example he revises from Seneca's story of Vedius Pollio, a knight in the court of Augustus who, incensed at a slave who shattered a crystal cup, threatened to feed him to carnivorous morays (see Ira 3.40.2). Here's Kant's version:

The rich person, whose servant clumsily breaks a beautiful and rare crystal goblet while carrying it around, would think nothing of this accident if, at the same moment, he were to compare this loss of one pleasure with the multitude of all the pleasures that his fortunate position as a rich man offers him. (Anth 7:254)

The rich man, were he to reflect, would compare the loss of the one pleasure (i.e. of owning an intact crystal goblet) against all that his station in life afford him. What he would reject, were he to reflect, is a claim — something along the lines of: I've been robbed of something significant to my life's going well. ${ }^{41}$ The affect, in other words, makes a claim. He doesn't reflect, so he by default "gives himself up" to the affect, or tacitly endorses that claim.

Consider now how Kant explains affect in the Metaphysics of Morals: affect is "weakness in the use of one's understanding combined with the strength of mental movement [Gemüthsbewegung]" (6:408). Here he's explicit that affect is a combination of some kind: but how does this definition relate to the account of affect that I have been advancing? Kant's talk of the "weakness of understanding" may allude to the Stoic conception of opinion, which they explain in terms of "weakness" of assent ${ }^{42}$ — though I won't try to defend that claim here. On my account, the rich man's affect is a combination of a pain-feeling and a presentation of a

\footnotetext{
${ }^{41}$ Epictetus relatedly counsels against supposing that one's happiness consists in "something like a jar or a crystal goblet" (Discourses 3.24.84-5).

${ }^{42}$ See, e.g., Cicero, Academica 1.41-2.
} 
shattered cup, where the combination makes the claim that I've been robbed (etc.). It makes that claim because feeling is a mode of self-manifestation; and the affect is that self-manifestation bound up with viewing the world in a certain way. Now, Kant explains Gemüthsbewegung in anthropology lectures from the mid-1780s as "a feeling of pleasure or displeasure that draws our entire attentiveness to it" (VA-Mrongovius 25:1340). So our rich man's attention is drawn to a feeling of displeasure; but this displeasure is how he feels himself, with the presentation of the shattered cup. His mentality is consumed with the combination of the two - consumed by the claim of the affect, in other words - so that no other consideration enters in. This is quite readily understood as a "weak" or unsound use of understanding, one made possible with a particular "strength of mental movement" that binds the mind into a hard certainty which indisposes one for reflection.

The outlines of this conception of affect plausibly draw from two important passages in Seneca's De Ira (1.8.1-3 and 2.1-4), as I will suggest next. Looking into this source will help us understand more precisely how Kant conceives of affect as an expression of rationality.

\subsection{Seneca on pathos ${ }^{43}$}

I began this paper by pointing to the standard objection that psychological monism cannot account for affections' assailing us against our will. Seneca, I noted, does not brush this phenomenological claim aside, but acknowledges it by likening the mind undergoing pathos to a body in freefall (Ira 1.7.4; cf. 3.1.4). Yet the movement Seneca is interested in is initiated by rationality: we are not pushed off the proverbial precipice; rather, we leap. ${ }^{44}$ Hence Seneca's advice: "The best course is to reject straightway the initial prickings [primum irritamentum] of anger" (1.8.1) - to accept this "irritation" would be to hurl oneself off the precipice. But what exactly is the nature of this irritation? And what is it to accept it, or reject it? These questions become more urgent as Seneca switches to another metaphor, one appearing to cast pathos as an "enemy" that "must be held at bay on the first frontier" (1.8.2). The imagery of boundaries breached does not obviously accord with the principles of monism; and "letting in" an enemy seems more like a euphemism for being overcome by a powerful alien force, rather than anything done voluntarily, like the leap. And yet Seneca insists on the principles of monism as he continues: "the mind is not sequestered, keeping watch for the pathe as things external and apart [...]. Rather, the mind turns itself into the pathos" (1.8.2).

\footnotetext{
${ }^{43}$ See $n 34$ on terminology.

${ }^{44}$ The image develops an analogy attributed to Chrysippus: a pathos is like a runner who, though he has initiated his own movement, cannot immediately stop himself (PHP 4.2.8-18).
} 
Thus Seneca makes a point of both acknowledging the phenomenology of assailment while at the same time insisting on a monistic account of pathe; but he does not explain how he holds the two together until the beginning of De Ira 2. His question there is "whether anger begins with an act of judgment or with a mere impulse — that is, whether it is set in motion voluntarily or is like many things that come about inside us without our being aware" (2.1.1). Even asking this question might be interpreted as openness to dualism, since Stoics normally take "impulse" in this context to refer to rational impulse - i.e. one originating in assent to some axioma. ${ }^{45}$ But this impulse is the "initial prickings" referred to earlier (Ira 1.8.1), here called an “initial mental jolt [primus ... ictus animi]" (2.2.2; cf. prima ... agitatio animi, 2.3.5). ${ }^{46}$ Seneca's aim here is to distinguish this jolt, which he explains is non-rational, from the genuine pathos, which is rational. More particularly, Seneca sets out to show how the jolting factor can be associated with the pathos, but not confused with it: and in this way, he accommodates the phenomenology of assailment in the context of a monistic analysis of pathè. In doing so, Seneca advances our understanding of what makes pathè rational. ${ }^{47}$

The key point is that the initial jolt is something simple (simplex), while the pathos is complex, combining several elements (compositus et plura continens, 2.1.5). ${ }^{48}$ Thus Seneca explains anger as involving the following combination:

having the impression of having received an injury [speciem capere acceptae iniuriae], desiring to take vengeance for it, and then combining both in the judgment that one ought not to have been harmed and that one ought to be avenged [...]. (2.1.4; translation modified)

Anger, as a complex impulse, expresses assent not just to (a) the impression of having received an injury, nor additionally to (b) desiring to take vengeance; rather, it expresses assent to the combination of these, a judgment about what is a reason for doing what. Yet we need to understand what makes this an impulse — something that, in Stoic psychology, is sufficient for action. Another source explains that "assents are to one thing, and impulses to another: assents are to propositions [axiōmata], impulses are toward predicates [epi katégorémata] that are somehow contained in the propositions to which they assent" (Arius in Stob 2.88). ${ }^{49}$ To have a rational

\footnotetext{
${ }^{45}$ Hence Kaster's addition of "mere" — the Latin is just ira utrum iudicio an impetu incipiat.

${ }^{46}$ Seneca is discussing what was referred to in wider Stoic circles as propatheiai; for discussion see Graver $(2007,98)$.

${ }^{47}$ My understanding of the passage is heavily indebted to Inwood (2005). Inwood responds in that article to a tradition of reading Seneca as a eclectic who abandons Stoic psychological monism, in light of both Ira 2.1.1-5 and Ep 92.1-2. The latter passage does not bear directly on the account of pathè, so I have not considered it here.

${ }^{48}$ Ira 2.1.5 is unaccountably missing from Kaster's translation.

${ }^{49}$ My translation, which draws on that in Annas (1992:93-4).
} 
impulse, then, is to think oneself as the subject of the relevant predicate, expressible in incomplete form as an infinitive - e.g. to avenge this injury (see Annas 1992, 94).

Seneca distinguishes the "jolt" from the pathos as simple and complex impulse; but we need to understand that simplicity and complexity. A clue lies in Seneca's distinguishing the jolt, as something bodily, from the pathos, as something mental (or rational, on Stoic terms). As we have just seen, Seneca explains the complexity of the pathos in terms of its involving the sort of combination that is required to take a view of what is a reason for believing and doing what. Then Seneca explains that the "initial mental jolt" belongs to a group of bodily reactions that we cannot be reasoned out of having (2.2.1), that "happen to us just because of our lot as humans, and happen, accordingly, even to the very wise" (2.2.2). Such bodily reactions include "shivering when we're sprinkled with cold water, $[\ldots]$ revulsion at touching certain things, $[\ldots]$ the blush that spreads when we hear obscene words, $[. .$.$] the dizziness that comes over us when we look$ down from a cliff' (2.2.1), as well as blanching, and crying (2.3.2-3). Seneca is not asserting that the "jolt" associated with a pathos must be any of those things, only that it is relevantly like them. Seneca explains this class as "responses that merely chance to move the mind: the mind doesn't so much cause them as suffer them" (2.3.1). So he is allowing that these "involuntary bodily movements" (2.3.2) are triggerings of mentality, but they are not themselves mental: they are stimuli that put one on guard. But our being jolted in these sorts of ways does not, as such, involve any genuine belief about how things are, nor do they compel any first-personal justificatory thought about what is a reason for doing what. This is how Seneca expands this class of "jolts" to include certain reactions when we attend theatre, read ancient history, listen to music, or contemplate horrific images (2.2.3-4). With this, it becomes clear that the standard of what counts as rational in the relevant sense is not simply that it requires the resources of a rational mind - e.g. reading ancient history surely requires that - but rather that it more particularly involves the act of combination required for first-personal justificatory thought.

Although we have been considering how the "jolt" is distinguished from the pathos, we must also see how they are associated in order to understand Seneca's advice to "reject straightway the initial prickings of anger" (1.8.1). Seneca says repeatedly that the impression of injury, in the present example, "stirs" us (movet, 2.2.2), while he also denies that this being-stirred is itself any pathos (2.3.1, also 2.3.5). This being-stirred, the "jolt", is a stun produced by the impression of, e.g., a shattered goblet; but it is not itself mental, though it triggers mentality. Anger requires " $[t]$ he intentional movement that follows, which has not only taken in the impression but affirmed it — that's anger, the arousal of a mind that moves willingly and deliberately toward the goal of vengeance" (2.3.5). Thus Seneca gives his advice in shorthand: 
for the "initial prickings" are a mental irritation, and not the sort of thing that can be rejected. It's just there. His advice is to refuse the way in which this stimulus fixes our attention on the impression of injury, in a manner that disposes us — but does not as such compel us — to affirm its claim.

\subsection{Concluding observations}

Kant, I have argued, understands affects to be rational on terms akin to those by which Seneca explains pathe as rational: namely, as involving the kind of combination that is required to express a rational, justificatory point of view. In the terms of Kant's faculty psychology, the angry rich man has a cognitive presentation of a shattered crystal goblet which is bound up with a painful feeling, yielding the claim of the affect — I've been robbed of something of significance to my life's going well. The affect itself is explained as a feeling that does not allow him to rise to reflection, the consideration of whether to give himself up to the affect, or to refuse it. The affect cannot be something that simply happens to him, or else it would not make sense to speak in these terms. The affect would just be there, like a sneeze or a shudder. Rather, what would be in the offing for one to "give oneself up to" or "refuse" must be something that a rational being can in principle commit himself to, which can only be the claim of the affect. Since a person in the throes of affect is momentarily indisposed to reflect, he endorses the claim by default, thereby expressing an evaluative point of view..$^{50}$

I have also argued that while Seneca distinguishes the "jolt" from the pathos, he also takes them to be associated with one another in what might be conceived as the broader experience of the pathos. This wider association allows Seneca to acknowledge the phenomenology of assailment without forfeiting a monistic analysis of pathe. Kant, as I've noted, emphasises the suddenness or joltingness of affect; and he sometimes strays into supposing that affects are just that — something that happens to us, like a squall we need only wait to pass (e.g. MS 6:408). Yet Kant expressly makes a point of distinguishing involuntary bodily reactions that are associated with affects but not to be confused with them. ${ }^{51}$ In presenting laughter as an affect, he makes clear that he does not mean " $[t]$ he jerky (nearly convulsive) exhaling of air attached to laughter"; he rather means amusement, something mental (Anth 7:262). In an appended remark, Kant elaborates that "certain internal bodily feelings" — here he mentions items akin to Seneca's list of involuntary bodily reactions, like shuddering at a ghost story, shivering in a rainshower,

\footnotetext{
50 This talk of "endorsement" nods to the Stoic terms usually translated "assent".

${ }^{51}$ Borges (2008) by contrast argues that affects have integral bodily component, proposing Kant's account is based in eighteenth-century physiology.
} 
dizziness looking down from a height (7:263-4) — may be "related to affects" but should not be confused with them $(7: 263)$. Although Kant does not make explicit what he takes to be the philosophical significance of this distinction, he notes that these associated "bodily feelings" differ from affects in that they "are only momentary, transitory, and leave no trace of themselves behind' (7:263; my emphasis) Since Kant often presents affects (in distinction from passions) as momentary and transitory, the crucial point must be the last: the associated bodily movements leave no trace, while affects do. On my account, the point of the distinction becomes quite clear: to have an affect is to endorse - albeit unreflectively, and only momentarily — a certain evaluative point of view, which leaves a trace in the person herself, at least inasmuch as it informs the adoption of particular practical commitments that may ultimately settle in as passions, and constitute character. ${ }^{52}$

Yet Kantian affects are practically underdetermined, as Kantian passions, which involve settled maxims, and Stoic pathè, which are rational impulses, cannot be. Kant offers an illustration of the point in his remarks on the affect of astonishment (Verwunderung). A background interest in comprehension makes an astonishing thing interesting: so while astonishment at encountering something that one cannot make sense of initially "impedes the natural play of thought", and is thereby disagreeable, in the natural course of things it "promotes the influx of thought to the unexpected representation all the more" - and stimulates inquiry (Anth 7:261). But it does not have to go like that: a person "who has become acquainted with the course of things through varied experience" may make it "a principle to be surprised at nothing (nibil admirar)" (7:261). Alluding to Horace's Epistle 1.6, Kant imagines someone who regards astonishment as a threat to his own even-keel self-command, and adopts the maxim to "marvel at nothing", nil admirari. The Horace-figure illustrates a kind of perversion that Kant then contrasts with someone for whom astonishment leads to inquiry — and eventually to a kind of dispositional admiration (Bewunderung) at "the order of nature in its great variety" that ultimately displays "a wisdom that he did not expect" (7:261). The admiration that Kant invokes here is an important topic unto itself, closely related to the moral feeling of respect: both are appropriate attitudes to the existence, or manifest traces, of rationality in the world — indeed, this too is the admiratio that Kant excluded from the target of apathy (recall \$3). While we cannot examine this issue here, we can see that Kant treats astonishment as a precursor to admiration at least when we develop as we should.

\footnotetext{
${ }^{52}$ Here too Kant's affect-passion distinction closely follows the pathos-morbi distinction presented in $\$ 3.2$ : the pathe (or affects) leave traces that can develop into morbi (or passions) if repeated. An anonymous referee reminds me that Seneca (Ira 1.16.7) points to Zeno's view that these traces may be retained, but only as a kind of scar, in the wise person.
} 
Since Kantian affects are practically underdetermined, what drives this development cannot lie in the affect itself. Recall, then, Sherman's charge that Kant nods to an affective profile of virtue, but lacks the resources to explain how we get there ( $\$ 2.3)$. Sherman's charge rests on the assumption that Kant is a psychological dualist, leaving her to treat affects as expressions of a non-rational part of us - and as such, unable to lodge a claim that we can go right or wrong in endorsing. I have argued that this underlying assumption, which goes chronically unquestioned in the literature, is unfounded. What its rejection might mean for Kant's view of moral development is another story — one that needs to consider the broader scope of affections, and not just the targets of apathy with which I have chiefly been concerned here. $^{53}$

${ }^{53}$ I would like to thank an editor and three anonymous referees for this journal for their comments, and Markos Valaris - as ever - for much support, philosophical discussion, and comments on an earlier version of this paper. I would like to express my gratitude to the Australian Research Council for funding (FT180100494) that made the research for this paper possible. 


\section{REFERENCES}

\section{KANT}

References to Kant's works follow volume and page of the German Academy edition: Kants Gesammelte Schriften (Berlin: de Gruyter, 1900-). Quotations follow those in the following volumes of Cambridge Edition of the Works of Immanuel Kant (Cambridge: Cambridge University Press) where available, but are modified on occasion:

Kant, Immanuel. 1996a. Practical Philosophy. Translated by M. Gregor.

—. 1996b. Religion and Rational Theology. Translated by A. Wood et al.

- 2000. Critique of the Power of Judgment. Translated by P. Guyer et al.

- 2007. Anthropology, History, and Education. Translated by R. Louden et al.

- 2015. Lectures on Anthropology. Translated by A. Wood et al.

These title abbreviations are used: Anth=Anthropology from a Pragmatic Point of View; $\mathbf{K p V}=$ Critique of Practical Reason; $\mathbf{K U}=$ Critique of the Power of Judgment; $\mathbf{M S}=$ Metaphysics of Morals; $\mathbf{R e l}=$ Religion within the Boundaries of Reason Alone.

\section{OTHER PRIMARY SOURCES}

Ancient sources are cited in conventional ways, using the abbreviations noted in bold below. Seneca's De Ira is abbreviated Ira, and appears in Seneca (1928) and (2010). Quotations are drawn from any separately listed English translations (e.g. Cicero 2002, not Cicero 1927).

Cicero. 1927. Tusculan Disputations. Translated by J.E. King. Cambridge, MA: Harvard University Press. [TD]

Cicero. 1997. The Nature of the Gods. Translated by P.G. Walsh. Oxford: Clarendon Press. [ND]

Cicero. 1933. De Natura Deorum and Academica. Translated by H. Rackham. Cambridge, MA: Harvard University Press.

Cicero. 2002. Cicero on the Emotions: Tusculan Disputations 3 and 4. Translated by M. Graver. Chicago: University of Chicago Press. [TD]

Diogenes Laertius. 1925. Lives of the Eminent Philosophers. Translated by R.D. Hicks. Cambridge, MA: Harvard University Press. [DL]

Epictetus. 1928. Discourses, Books 3-4. Translated by W.A. Oldfather. Cambridge, MA: Harvard University Press.

Galen. 1981. De Placitis Hippocratis et Platonis. Translated and edited by P. de Lacy. Berlin: Akademie Verlag. [PHP]

Horace. 1926. Satires, Epistles, The Art of Poetry. Translated by H. R. Fairclough. Cambridge, MA: Harvard University Press.

Seneca. 1917, 1920, and 1925. Epistulae Morales. Translated by R.M. Gummere. 3 vols. Cambridge, MA: Harvard University Press. [Ep] 
Seneca. 1928. Moral Essays. Translated by J.W. Basore. Cambridge, MA: Harvard University Press.

Seneca. 2007. Selected Philosophical Letters. Translated by B. Inwood. Oxford: Clarendon Press. [Ep]

Seneca. 2010. Anger, Mercy, Revenge. Translated by R. Kaster and M. Nussbaum. Chicago: University of Chicago Press.

Seneca. 2015. Letters on Ethics to Lucilius. Translated by M. Graver and A.A. Long. Chicago: University of Chicago Press, 2015. [Ep]

Seneca. 2016. Hardship and Happiness. Translated by E. Fantham et al. Chicago: University of Chicago Press.

Stobaeus, Iōannēs. 1884. Anthologium, ed. C. Wachsmuth and O. Hense. Vols 1-2. Berlin: Weidmann. [Stob]

\section{OTHER WORKS CITED}

Allison, Henry. 1990. Kant's Theory of Freedom. Cambridge: Cambridge University Press.

Annas, Julia. 1992. Hellenistic Philosophy of Mind. Berkeley: University of California Press.

Baron, Marcia. 1995. Kantian Ethics Almost without Apology. Ithaca: Cornell University Press.

Borges, Maria. 2008. "Physiology and the Controlling of Affects in Kant's Philosophy," Kantian Review 13(2): 46-66.

Boyle, Matthew. 2016. “Additive Theories of Rationality: A Critique," European Journal of Philosophy 24 (3): 527-55.

Brennan, Tad. 2003. "Stoic Moral Psychology." In Cambridge Companion to the Stoics, edited by Brad Inwood, 257-94. Cambridge: Cambridge University Press.

Cohen, Alix. 2020. “A Kantian Account of Emotions as Feelings,” Mind 129 (514): 429-460.

Cooper, John. 1999. "Posidonius on Emotions." In his Reason and Emotion: Essays on Ancient Moral Psychology and Ethical Theory, 449-484. Princeton: Princeton University Press.

Copp, David and David Sobel. 2002. "Desires, Motives, and Reasons: Scanlon's Rationalistic Moral Psychology," Social Theory and Moral Practice 28 (2): 243-276.

DeWitt, Janelle. 2018. "Feeling and Inclination: Rationalizing the Animal Within." In Kant and the Faculty of Feeling, edited by Kelly Sorensen and Diane Williamson, 67-87. Cambridge: Cambridge University Press. 
Frede, Michael. 1986. "The Stoic Doctrine of the Affections of the Soul." In The Norms of Nature: Studies in Hellenistic Ethics, edited by Malcolm Schofield and Gisela Striker, 93-110. Cambridge: Cambridge University Press.

Frede, Michael. 2011. A Free Will: Origins of the Notion in Ancient Thought. Berkeley: University of California Press.

Frierson, Patrick. 2014. Kant's Empirical Psychology. Cambridge: Cambridge University Press.

Graver, Margaret. 2007. Stoicism and Emotion. Chicago: University of Chicago Press.

Groß, Felix, ed. 1912. Immanuel Kant: sein Leben in Darstellungen von Zeitgenossen; die Biographien von L.E. Borowski, R.B. Jachmann und A. Ch. Wasianski. Berlin: Deutsche Bibliothek.

Inwood, Brad. 1985. Ethics and Human Action in Early Stoicism. Oxford: Clarendon Press.

Inwood, Brad. (2005 [1993]). "Seneca and Psychological Dualism.” In his Reading Seneca: Stoic Philosophy at Rome, 23-64. Oxford: Oxford University Press.

Lewis, Charlton and Charles Short. 1879 (1958). A Latin Dictionary. Oxford: Clarendon Press.

McLear, Colin. 2020. "Animals and Objectivity." In Kant on Animals, edited by John Callanan and Lucy Allais, 42-65. Oxford: Oxford University Press.

Merritt, Melissa. 2018. Kant on Reflection and Virtue. Cambridge: Cambridge University Press.

Merritt, Melissa. 2021. "Nature, Corruption, and Freedom: Stoic Ethics in Kant's Religion," European Journal of Philosophy 29 (1): 3-24.

Merritt, Melissa. Forthcoming. "Kant and Psychological Monism: the Case of Inclination." In Palgrave Handbook of German Idealism and Analytic Philosophy, edited by James Conant and Jonas Held. London: Palgrave Macmillan.

Naragon, Steve. 2006. "Kant in the Classroom: Materials to Aid the Study of Kant's Lectures." Last modified 3 June 2015. https://users.manchester.edu/Facstaff/SSNaragon/Kant/Home/index.htm

Nussbaum, Martha. 1997. "Kant and Stoic Cosmopolitanism," The Journal of Political Philosophy 5 (1): $1-25$.

Schafer, Karl. 2020. “A System of Rational Faculties: Additive or Transformative?” European Journal of Philosophy. DOI: 10.1111/ejop.12612

Schapiro, Tamar. 2009. “The Nature of Inclination,” Ethics 119 (2): 229-256.

Schneewind, Jerome. 1996. "Kant and Stoic Ethics." In Kant, Aristotle, and the Stoics, edited by Stephen Engstrom and Jennifer Whiting, 285-301. Cambridge University Press.

Seidler, Michael. 1981. "Kant and the Stoics on the Emotional Life," Philosophy Research Archives 7: 1109-1150. 
Sherman, Nancy. 1997. Making a Necessity of Virtue: Aristotle and Kant on Virtue. Cambridge: Cambridge University Press.

Sherman, Nancy. 2013. "Moral Psychology and Virtue." In The Oxford Handbook of the History of Ethics, edited by Roger Crisp, 744-67. Oxford: Oxford University Press.

Shogry, Simon. 2019. "What Do Our Impressions Say? The Stoic Theory of Perceptual Content and Belief Formation," Aperion 52 (1): 29-63.

Sorabji, Richard. 2000. Emotion and Peace of Mind: from Stoic Agitation to Christian Temptation. Oxford: Oxford University Press.

Varden, Helga. 2020. Sex, Love, and Gender: a Kantian Theory. Oxford: Oxford University Press.

Wilson, Eric Entrican. 2016. "Habitual Desire: On Kant’s Concept of Inclination,” Kantian Review 21 (2): 211-235.

Wood, Allen. 1999. Kant's Ethical Thought. Cambridge: Cambridge University Press.

Wood, Allen. 2011. "Kant and Agent-Oriented Ethics." In Perfecting Virtue: New Essays on Kantian Ethics and Virtue Ethics, edited by Lawrence Jost and Julian Wuerth, 58-91. Cambridge: Cambridge University Press.

Wood, Allen. 2018. "Feeling and Desire in the Human Animal." In Kant and the Faculty of Feeling, edited by Kelly Sorensen and Diane Williamson, 88-106. Cambridge: Cambridge University Press. 